\title{
Management of Neurorehabilitation During the COVID-19 Pandemic
}

\author{
COVID-19 Pandemisi Sürecinde Nörorehabilitasyonun Yönetimi
}

\section{Şevki ŞAHİN \\ (i) 0000-0003-2016-9965}

Maltepe University Faculty of Medicine Department of Neurology, Istanbul, Turkey

\section{Corresponding Author Sorumlu Yazar \\ Şevki ŞAHIN \\ drsahin@gmail.com}

Received / Geliş Tarihi : 28.07.2020 Accepted / Kabul Tarihi : 15.10.2020 Available Online /

Çevrimiçi Yayın Tarihi : 25.11.2020

\begin{abstract}
Neurorehabilitation originates from the concept of neuroplasticity and it has an important role -both physical and cognitive- in the restoration of a damaged nervous system. Interruption in neurorehabilitation negatively affects a patient's prognosis. Unfortunately, after the World Health Organization declared coronavirus disease 2019 (COVID-19) a pandemic, there were some disruptions in neurorehabilitation practices. Therefore, according to the principles of infection prevention and protection, the issue of developing new neurorehabilitation management strategies was raised. Providing appropriate physical distancing in shared rehabilitation areas and strict training of the rehabilitation team with regard to hygiene rules are important issues in terms of preventing contamination. In new treatment schemes, options such as discharging patients from hospital at the earliest possible time, home-based treatments and telerehabilitation have become standard. Online patient-physician consultation can provide the continuity of neurorehabilitation and reduce anxiety and the feeling of social isolation felt by many patients and their families. In addition, the pandemic period can be turned into an opportunity for caregivers to learn physical and cognitive exercises and apply them to their patients. The current article focuses on the new neurorehabilitation approaches in the neurological diseases sample which includes stroke, multiple sclerosis, dementia, Parkinson's disease and neuromuscular diseases within the context of the COVID-19 pandemic.
\end{abstract}

Keywords: COVID-19; neurorehabilitation; home-based treatment; telerehabilitation.

ÖZ

Nörorehabilitasyon nöroplastisite kavramından köken alır ve hasarlanmış sinir sisteminin restorasyonunda hem fiziksel hem de bilişsel açıdan önemli bir role sahiptir. Nörorehabilitasyonda kesinti yaşanması hastanın prognozunu negatif yönde etkiler. $\mathrm{Ne}$ yazık ki, Dünya Sağlık Örgütü’nün koronavirüs hastalığı 2019 (coronavirus disease 2019, COVID-19)'u pandemi olarak ilan etmesinden sonra, nörorehabilitasyon uygulamalarında aksamalar olmuştur. Bu nedenle, enfeksiyon önleme ve koruma kurallarına göre yeni nörorehabilitasyon stratejileri geliştirme konusu gündeme gelmiştir. Ortak rehabilitasyon alanlarında uygun fiziksel mesafenin sağlanması ve rehabilitasyon ekibinin hijyen kuralları açısından sıkı eğitimi, bulaşmayı önleme açısından önemli konulardır. Yeni tedavi şemalarında, hastaların mümkün olan en kısa zamanda hastaneden taburcu edilmesi, evde yapılan tedaviler ve telerehabilitasyon gibi seçenekler ön plana çıkmaktadır. Çevrimiçi hasta-uzman görüşmesi, nörorehabilitasyonun devamlılığını sağlayacağı gibi hasta ve yakınlarının, anksiyetesini ve sosyal izolasyon duygusunu azaltabilir. Ayrıca pandemi dönemi, bakım verenlerin, fiziksel ve bilişsel egzersizleri öğrenerek hastalarına uygulamaları açısından bir firsata da dönüştürülebilir. Bu makalede, COVID-19 pandemisi bağlamında; inme, multipl skleroz, demans, Parkinson hastalığı ve nöromusküler hastalıkları içeren nörolojik hastalıklar örnekleminde, yeni nörorehabilitasyon yaklaşımlarına odaklanılmıştır.

Anahtar kelimeler: COVID-19; nörorehabilitasyon; evde tedavi; telerehabilitasyon. 


\section{INTRODUCTION}

Neurorehabilitation is a branch of neurology that includes multidisciplinary approaches such as motor skills improvement, psychosocial support, cognitive rehabilitation, nutritional and nursing care recommendations implemented in the wake of nervous system damage and focused on the patient's well-being (1). Neurorehabilitation supports recovery by using diverse treatment methods such as physical therapy (electrical stimulation, walking splints, manual and robotic exercises, virtual reality, etc.), cognitive training, language therapy, informative activities for patients and their relatives and reorganization of the patient's environment (2).

Neurorehabilitation is based on the concept of providing neural reorganization by triggering neuroplasticity, and it aims to enhance the functioning of intact neural circuits. Neurodegeneration and neuroregeneration run parallel to each other during both acute and chronic neurological diseases (3). Therefore, any delay in neurorehabilitation may negatively affect the prognosis of the diseases. Unfortunately, the disruptions which occurred in the neurorehabilitation of neurological disease cases especially in the coronavirus disease 2019 (COVID-19) lockdown period and the subsequent "controlled life period" included strict infection prevention rules (4).

Telerehabilitation and home-based treatment options seem a promising solution to overcoming the restrictions brought about by the COVID-19 pandemic (5). This article aims to review the new neurorehabilitation management strategies developed during the COVID-19 pandemic through examining examples of neurological diseases, including stroke, multiple sclerosis (MS), dementia, Parkinson's disease (PD) and neuromuscular diseases (NMDs).

\section{Stroke and Neurorehabilitation}

Due to the COVID-19 pandemic, the stroke care component in medical services has been reported to have decreased on average by $40 \%$. The reasons for this situation have been ascribed to the fact that a large part of hospital bed capacities are now reserved for COVID-19 patients and other patients' fear to attend emergency units lest they catch the virus (6).

In the case of acute stroke, if the patient's vital signs are stable, a speedy hospital discharge and short neurorehabilitation programs are recommended (7). Common rehabilitation areas should not be used if sufficient physical distancing is not possible. Instead, rehabilitation could take place in the patient's own room under suitable isolation conditions. In order to ensure safe contact (8), physiotherapists must be informed about the infection control procedures and the use of appropriate personal protective equipment (PPE).

If the patient's body temperature is above $38{ }^{\circ} \mathrm{C}$, rehabilitation should be postponed until the results of the COVID-19 test have been received. If the COVID-19 test is positive, the patient should be transferred immediately from the neurology service to the isolation ward. The general approach to patients showing no COVID-19 risks is for the rehabilitation specialist to instruct caregivers in basic exercises which can be done at home. In addition, patients should be encouraged to join the telerehabilitation follow-up programme, if available (9).

Telerehabilitation means using communication programs with electronic tools (mobile phone, computer) to provide internet-based rehabilitation services. The patient or caregiver can watch videos to improve motor, language and cognitive functions. However, telerehabilitation programs that can facilitate online meetings of physicians and physiotherapists with their patients at certain specified times are much more effective (10). In addition, this doctor-patient meeting using electronic media can reduce both patient anxiety and the isolation caused by stroke during the COVID-19 pandemic (5).

Home-based rehabilitation programs may be useful in stroke cases with mild neurological deficit (11). Therefore, patients with mild deficit and their caregivers should be encouraged to continue neurorehabilitation at home. It should be explained to them that the risk of COVID-19 will increase parallel to any prolonged hospitalization.

Nowadays, the importance of the 'specialized stroke centers' which have been established to provide highquality stroke care has been highlighted once again (12). In these centers, rules of hygiene must be strictly followed, and stroke cases suspected of being COVID-19 positive should be isolated immediately.

\section{Multiple Sclerosis and Neurorehabilitation}

Continuity of neurorehabilitation is a basic need in MS cases, especially for those having symptoms such as spasticity and fatigue (13). In the early lockdown period, in some countries (14), in patients with MS, it was reported that neurorehabilitation was fully discontinued and instead in the following weeks evolved into teleassessment and telerehabilitation by an individual or group video meeting. Similar delays in neurorehabilitation were experienced in our country at the beginning of the COVID-19 pandemic. Subsequently, however, under the leadership of the Turkish Neurological Society (TNS), Study Groups for Multiple Sclerosis, Neurorehabilitation and TNS COVID-19 have started to share informative images and videos with patients via social media. In our country, the development of the electronic basis required for telemedicine and telerehabilitation is already sufficient. These treatment and follow-up options will become widespread after medicolegal provisions are instituted.

Depression affects approximately $50 \%$ of patients with MS. The social isolation caused by quarantine may have increased depression. In MS, in combating spasticity, as well as depression and chronic fatigue, regular exercise is important. For the duration of the COVID-19 pandemic, patients should be encouraged to alternately perform cardiovascular and stretching exercises three times a week for 30 minutes (or every day, 10 minutes) at home (15). In addition, patients should be encouraged to learn effective exercises such as pilates for walking, balance, and posture from web based platforms.

In order to avoid Uhthoff's syndrome, patients should be informed about the importance of an adequate fluid intake and they must stop if there is an excessive increase in body temperature during exercise $(9,13)$. If the patients' disability status is high, a daily routine exercise programme should be maintained by rolling in the bed, frequent change of position, and the contraction of abdominal, gluteal and thigh muscles. For deformed joints and spastic muscles, caregivers should be informed about the range of motion and passive stretching exercises to be done twice every day (13). 


\section{Dementia and Neurorehabilitation}

Due to the nature of the disease, cases of dementia have limited access to accurate information about the COVID19 pandemic. They may forget mask wearing procedures or be agitated by them. This can expose them to a higher risk of infection (16). In our country, a quarantine for people aged 65 and over was imposed in the first 3 months of the pandemic and some facilities were provided for them to access their medications. Later, restrictions were gradually relaxed and it was announced by the media that dementia patients should act together with their caregivers. As a part of this process, it was permitted for the caregivers of certain dementia patients to intervene by telephone in the case of patients who had developed neuro-psychiatric problems. Afterwards, the caregivers were informed about cognitive and physical exercises that can be done at home, during routine hospital examinations, and via social media. In a study that compared the cognitive status of dementia cases in which a system called TV-AssistDem (TeleVision-based Assistive Integrated Service to support European adults living with mild DEMentia or mild cognitive impairment) was used during the lockdown period of COVID-19, researchers reported that there was a better cognitive status in the group using this system (17). This result indicates that telemedicine methods should be more widely used in the future.

Mild cases should be encouraged to do stretching, flexionextension, sit-to-stand and walking exercises in their home, at least twice a day under the observation of a caregiver. In addition, occupational activities such as knitting, painting, cleaning, and cooking should be suggested after safe conditions have been provided (18).

Cognitive stimulation therapy (CST) is a well-known cognitive training method that can be individualized and can be applied under home conditions. It reduces the rate of cognitive decline -especially in mild cases. CST includes certain therapeutic techniques such as reality orientation (talking about time, place and person) and reminiscence therapy (talking about past activities and experiences using prompts such as photographs or objects) (19). For the duration of the COVID-19 pandemic, we could inform caregivers about such simple techniques and suggest that they use them with their patients. In immobile dementia cases, active assisted or passive flexionextension movements and frequent positioning may prevent contractures, pressure ulcers and pain. To avoid aspiration pneumonia, caregivers should be taught to feed the patient while he/she is in an upright position (20).

Unfortunately, at the onset of the COVID-19 pandemic, there was a large loss of life among dementia patients staying in nursing homes. This was a wake-up call for the restructuring of nursing homes (21). Strict supervisory mechanisms have to be established by the authorities. Neurorehabilitation should be recommenced only after a reorganization of personal and common areas according to the rules of infection prevention has been established.

\section{Parkinson's Disease and Neurorehabilitation}

There is extensive scientific evidence to support the belief that exercise and daily physical activity are important elements in managing symptoms and potentially modifying disease progression in patients with PD (22). Performing walking, balance and posture exercises provides improvement in their quality of life and enables them to remain mobile for a long time. Home exercises should be carried out not only during this pandemic period, they must also be routinely continued lifelong. Doing exercises together with caregivers will increase the sense of socialization that is lacking in our patients and also reduce undesirable consequences such as falling (9).

In a study conducted in the early period of the pandemic it was shown that patients can be directed to exercise regularly with positive results obtained by using a telehealth-based coaching system called 'Engage-PD' for early-middle stage PD patients. However, in that study, only $52 \%$ of the targeted patients remained in the study. The authors explained this situation by claiming that some of the patients might have been limited in their ability both to access and to adapt to the telehealth system (22). In our country, this kind of system -which provides access remotely and allows follow-up and monitoring of exerciseshould be developed immediately for patients with PD.

\section{Neuromuscular Diseases and Neurorehabilitation}

Due to their nature, NMDs (neuromuscular junction diseases, motor neuron diseases, hereditary and acquired muscle diseases, etc.) can be more severe when affected by other neurological diseases, especially respiratory complications caused by COVID-19. Providing and implementing remote neurorehabilitation training programmes for these patients is particularly important. Neurorehabilitation of NMDs includes a wide spectrum of treatment techniques from physical therapy approaches that increase joint flexibility, muscle strength and endurance to methods for coping with aphasia and dysphagia (23). After COVID-19 was declared a pandemic, neurorehabilitation for almost all NMDs was suspended for the first two or three months at the recommendation of the disease and occupation associations in so many country like ours. Various websites in our country provide counseling exercises -and also promote a variety of support systems for self-rehabilitation.

The French Rare Health Care for Neuromuscular Diseases Network (FILNEMUS) has reported that patients were informed through their web sites. By sharing the contact information of the departments during the lockdown period (23), they also tried to provide patients with the opportunity for teleconsultation with experts.

In an Italian study, persons with NMD and healthy controls were compared regarding the effects of physical inactivity during the COVID-19 quarantine period. The International Physical Activity Questionnaire Short-Form (IPAQ-SF) and Short-Form Health Survey (SF-12) were used as the evaluating tools in this study. The results of the study suggested that physical inactivity was positively correlated with the presence of NMD, impaired gait, male gender and high body mass index. It was natural that physical inactivity was found to be associated with the NMD because it is well-known that the muscles of NMD patients are more prone to atrophy due to impaired oxygen and glucose metabolism (24). However, this study has certain limitations, one of which is its inclusion of a short quarantine period. Also, interviews with the participants about the 'pre' and 'during' quarantine days were done in the same session in this study. This might be a second limitation because of certain psychological effects quarantine has on a person's memory. Long-term studies including more data are needed. 


\section{CONCLUSION}

In conclusion, discontinuation of neurorehabilitation could be negatively affecting the prognosis of neurological diseases in the COVID-19 pandemic. Aside from the negative effects of the disease itself, social isolation and fear of death made our patients more depressed. There is a need for a new system with less physical but more informational contact between the patient and the doctor. The general population and the medical community both should be conscious of this issue. Among the newly developed neurorehabilitation management strategies, telemedicine-supported home-based approaches seem to be promising for the future.

Conflict of Interest: None declared by the authors.

Financial Disclosure: None declared by the authors.

Acknowledgements: None declared by the authors.

\section{REFERENCES}

1. Kitago T, Krakauer JW. Motor learning principles for neurorehabilitation. Handb Clin Neurol. 2013;110:93103.

2. Fujiwara T, Ushiba J, Soekadar SR. Neurorehabilitation: Neural plasticity and functional recovery 2018. Neural Plast. 2019;2019:7812148.

3. Dimitrijevic MR. Outline of restorative neurology: definition, clinical practice, assessment, intervention. Clin Neurol Neurosurg. 2012;114(5):428-31.

4. Leocani L, Diserens K, Moccia M, Caltagirone C. Disability through COVID-19 pandemic: Neurorehabilitation cannot wait. Eur J Neurol. 2020; [Epub ahead of print]. doi: 10.1111/ene.14320.

5. Chang MC, Boudier-Revéret $M$. Usefulness of telerehabilitation for stroke patients during the COVID-19 pandemic. Am J Phys Med Rehabil. 2020;99(7):582.

6. Sylaja PN, Srivastava MVP, Shah S, Bhatia R, Khurana D, Sharma A, et al. The SARS-CoV2/COVID-19 pandemic and challenges in stroke care in India. Ann N Y Acad Sci. 2020; [Epub ahead of print]. doi: 10.1111/nyas.14379.

7. Bartolo M, Intiso D, Lentino C, Sandrini G, Paolucci $\mathrm{S}$, Zampolini $\mathrm{M}$, et al. Urgent measures for the containment of the coronavirus (Covid-19) epidemic in the neurorehabilitation/rehabilitation departments in the phase of maximum expansion of the epidemic. Front Neurol. 2020;11:423.

8. Smith EE, Mountain A, Hill MD, Wein TH, Blacquiere D, Casaubon LK, et al. Canadian stroke best practice guidance during the COVID-19 pandemic. Can J Neurol Sci. 2020;47(4):474-8.

9. Acar T, Demirel Acıman E, Afsar N, Akcalı A, Akman Demir G, Alagöz AN, et al. The COVID-19 from neurological overview. Turk J Neurol. 2020;26(2):58108.

10. Blacquiere D, Lindsay MP, Foley N, Taralson C, Alcock S, Balg C, et al. Canadian stroke best practice recommendations: telestroke best practice guidelines update 2017. Int J Stroke. 2017;12(8):886-95.

11. Gelaw AY, Janakiraman B, Gebremeskel BF, Ravichandran H. Effectiveness of home-based rehabilitation in improving physical function of persons with stroke and other physical disability: A systematic review of randomized controlled trials. J Stroke Cerebrovasc Dis. 2020;29(6):104800.

12. Zhao J, Rudd A, Liu R. Challenges and potential solutions of stroke care during the coronavirus disease 2019 (COVID-19) outbreak. Stroke. 2020;51(5):1356-7.

13. Naser Moghadasi A, Azadvari M, Sahraian MA. Rehabilitation recommendations for multiple sclerosis patients during the COVID-19 pandemic. Arch Iran Med. 2020;23(7):509-10.

14. Sastre-Garriga J, Tintoré M, Montalban X. Keeping standards of multiple sclerosis care through the COVID-19 pandemic. Mult Scler. 2020;26(10):1153-6.

15. Kalb R, Brown TR, Coote S, Costello K, Dalgas U, Garmon E, et al. Exercise and lifestyle physical activity recommendations for people with multiple sclerosis throughout the disease course. Mult Scler. 2020;26(12):1459-69.

16. Wang H, Li T, Barbarino P, Gauthier S, Brodaty H, Molinuevo JL, et al. Dementia care during COVID-19. Lancet. 2020;395(10231):1190-1.

17. Goodman-Casanova JM, Dura-Perez E, Guzman-Parra J, Cuesta-Vargas A, Mayoral-Cleries F. Telehealth home support during COVID-19 confinement for community-dwelling older adults with mild cognitive impairment or mild dementia: Survey study. J Med Internet Res. 2020;22(5):e19434.

18. Marx KA, Scott JB, Piersol CV, Gitlin LN. Tailored activities to reduce neuropsychiatric behaviors in persons with dementia: Case report. Am J Occup Ther. 2019;73(2):7302205160p1-9.

19. Ali A, Brown E, Spector A, Aguirre E, Hassiotis A. Individual cognitive stimulation therapy for people with intellectual disability and dementia: protocol of a feasibility randomised controlled trial. BMJ Open. 2018;8(12):e022136.

20. Coronado RA, Albers HE, Allen JL, Clarke RG, Estrada VA, Simon CB, et al. Pain-reducing effects of physical therapist-delivered interventions: A systematic review of randomized trials among older adults with dementia. J Geriatr Phys Ther. 2020;43(3):159-69.

21. Trabucchi M, De Leo D. Nursing homes or besieged castles: COVID-19 in northern Italy. Lancet Psychiatry. 2020;7(5):387-8.

22. Quinn L, Macpherson C, Long K, Shah H. Promoting physical activity via telehealth in people with parkinson disease: The path forward after the COVID19 pandemic? Phys Ther. 2020;100(10):1730-6.

23. Solé G, Salort-Campana E, Pereon Y, Stojkovic T, Wahbi K, Cintas P, et al. Guidance for the care of neuromuscular patients during the COVID-19 pandemic outbreak from the French Rare Health Care for Neuromuscular Diseases Network. Rev Neurol (Paris). 2020;176(6):507-15.

24. Di Stefano V, Battaglia G, Giustino V, Gagliardo A, D'Aleo M, Giannini O, et al. Significant reduction of physical activity in patients with neuromuscular disease during COVID-19 pandemic: the long-term consequences of quarantine. J Neurol. 2020; [Epub ahead of print]. doi: 10.1007/s00415-020-10064-6. 